\title{
PENERAPAN PRINSIP-PRINSIP GOOD CORPORATE GOVERNANCE \\ DALAM PENGELOLAAN WAKAF TUNAI PADA BADAN WAKAF UANG TUNAI MUI YOGYAKARTA
}

\author{
Ananto Triwibowo \\ Sekolah Tinggi Ekonomi dan Bisnis Islam Lampung \\ E-Mail: ananto112793@gmail.com
}

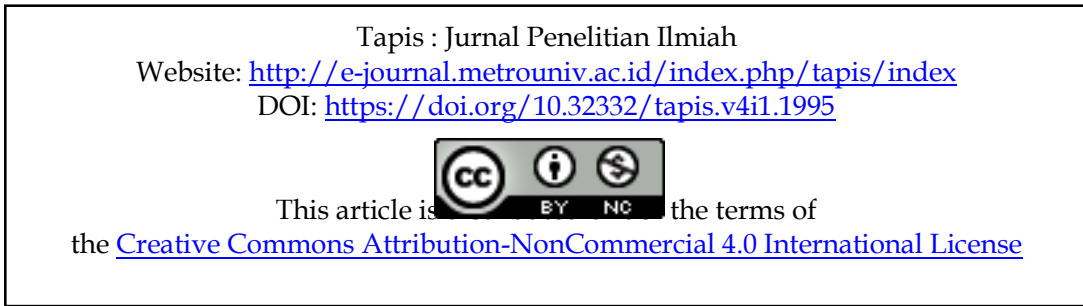

\begin{abstract}
As a public institution that has a mandate to manage the waqf cash fund, the waqf agency is required to be capable of managing the cash waqf fund and implementing the principles of Good Corporate Governance (GCG) as a form of responsibility to public The impact of the implementation of GCG itself, in addition to improve the level of public trust, will increase the amount of fund accepted by the waqf agency. This research aims to describe the management of cash waqf and to analyze the implementation of Good Corporate Governance (GCG) principles respectively done and in BWU/T MUI DIY in the management of cash waqf.

This is a qualitative-descriptive research using a case study approach aimed to describe the reality of the cash waqf management and the implementation of GCG principles in BWU/T MUI DIY. The results were then analyzed or measured using the theories relevant with the issues concerned. In addition, this research used SWOT analysis to observe the strengths, weaknesses, opportunities and challenges in managing the cash waqf faced by the BWU/T MUI DIY.

Based on the results of the research, it can be found that in the management of the cash waqf done by BWUT MUI DIY overall has been implemented in accordance with the existing laws, either from legislation, regulation of religion minister, and regulation issued by BWI. Meanwhile for the implementation of GCG principles in the management of cash waqf done by BWUT MUI DIY recently has not been done maximally. Of five basic principles of GCG including transparency, accountability, responsibility, independence and fairness, in fact there are only two principles conducted entirely that is the principle of independence and fairness. On the other hand, the principles of transparency, accountability, and responsibility have not been applied entirely.
\end{abstract}

Keywords: Good Corporate Governance Principles, Cash Waqf Management 


\begin{abstract}
Abstrak
Sebagai lembaga publik yang mendapatkan amanah untuk mengelola dana wakaf tunai, lembaga wakaf dituntut untuk bisa menerapkan prinsip-prinsip Good Corporate Governance sebagai bentuk pertanggungjawaban kepada masyarakat luas. Dampak dari penerapan GCG sendiri selain akan meningkatkan tingkat kepercayaan masyarakat juga akan meningkatkan jumlah dana yang diterima oleh lembaga wakaf. Penelitian ini bertujuan untuk mendeskripsikan pengelolaan wakaf tunai yang dilakukan oleh BWU/T MUI DIY serta menganalisis penerapan prinsip-prinsip GCG pada BWU/T MUI DIY dalam pengelolaan wakaf tunai.

Jenis penelitian yang digunakan adalah kualitatif deskriptif dengan menggunakan pendekatan studi kasus yang bertujuan untuk menggambarkan realitas tentang pengelolaan wakaf tunai dan penerapan prinsip-prinsip GCG pada BWU/T MUI DIY yang kemudian dianalisis atau melakukan pengukuran dengan menggunakan teori-teori yang relevan dengan masalah yang diangkat. selain itu penelitian ini juga menggunakan analisis SWOT untuk mengetahui kekuatan, kelemahan, peluang, tantangan dalam pengelolaan wakaf tunai yang dihadapi oleh BWU/T MUI DIY.

Berdasarkan hasil dari penelitian dapat diketahui bahwa dalam pengelolaan wakaf tunai yang dilakukan oleh BWU/T MUI DIY secara keseluruhan sudah sesuai dengan regulasi yang ada baik dari perundang-undangan, peraturan menteri agama, dan juga peraturan yang ditetapkan oleh BWI. Sedangkan untuk penerapan prinsipprinsip GCG pada pengelolaan wakaf tunai yang dilakukan oleh BWU/T MUI DIY selama ini belum dilaksanakan secara maksimal. Dari kelima prinsip dasar GCG yakni transparasi, akuntabiltas, responsibilitas, idependesnsi dan juga fairness ternyata hanya dua prinsip yang dilaksanakan secara utuh yakni prinsip indepedensi dan juga fairness. Sedangkan untuk prinsip transparasi, akuntabiltas, dan juga responsibiltas belum dilaksanakan secara utuh.
\end{abstract}

Kata Kunci: Prinsip-Prinsip Good Corporate Governance, Wakaf Uang Pengelolaan

\title{
A. PENDAHULUAN
}

Dalam istilah ekonomi Islam wakaf menjadi salah satu instrumen penting dalam pendistribusian pendapatan. Dengan adanya wakaf ini diharapkan mampu untuk membantu dalam pengentasan kemiskinan. Wakaf dalam Islam sudah dikenal bersamaan dengan dimulainya era kenabian Muhammad saw. Ditandai dengan pembangunan Masjid Quba. Kemudian disusul dengan pembangunan Masjid Nabawi yang dibangun di atas tanah anak yatim dari Bani Najjar yang dibeli Rasulullah saw. Rasulullah saw mewakafkan tanah yang dibelinya itu 
untuk dibangun masjid, dan kemudian para sahabat memberikan sokongan berupa wakaf untuk penyelesian pembangunan masjid tersebut ${ }^{1}$.

Seiring dengan perkembangan zaman, kini wakaf pun juga mengalami perkembangan dalam bentuk pengelolaanya. Dalam sejarah, sebagai mana disebutkan oleh Syafi'i Antonio bahwa pengelolaan ini tidak lepas dari periodesasi pengelolaan wakaf secara umum yakni periode tradisonal, periode semi profesional, dan periode profesional ${ }^{2}$. Peluang yang lebih besar muncul akhirakhir ini dengan disahkan rancangan Undang-undang Wakaf menjadi Undangundang Nomor 41 Tahun 2004 tentang Wakaf. Kehadiran Undang-undang Wakaf itu memberikan harapan kepada semua pihak dalam upaya pemberdayaan ekonomi rakyat, di samping untuk kepentingan peribadatan dan sarana sosial lainnya ${ }^{3}$. Sebagai tindak lanjut dari lahirnya Undang-undang Wakaf, banyak bank syariah dan lembaga pengelola wakaf meluncurkan produk dan fasilitas yang menghimpun dana wakaf tunai dari masyarakat.

Namun fenomena yang terjadi saat ini bahwa manfaat wakaf dan wakaf tunai pada khususnya, kurang dapat dirasakan dan didayagunakan secara optimal untuk peningkatan kualitas kehidupan masyarakat di Indonesia. Ada beberapa kendala yang menyebabkan perihal tersebut diantaranya adalah aspek kelembagaan, aspek kesadaran hukum masyarakat, dan aspek manajemen .

Salah satu aspek kelembagaan dan managemen adalah kurangnya tranparasi lembaga wakaf terhadap masyarakat yang mengakibatkan kurangnya tingkat kepercayaan masyarakat terhadap lembaga wakaf tersebut dan akan berpengaruh pada dana wakaf yang diterima karena masyarakat lebih memilih untuk mewakafkan harta mereka secara langsung. Serta kurangnya jumlah nazhir yang profesional dan belum optimalnya lembaga lembaga pengelola wakaf dalam mengelola wakaf yang semestinya keberadaanya menjadi faktor penentu dalam

\footnotetext{
${ }^{1}$ Suhrawardi K. Lubis, dkk., Wakaf dan Pemberdayaan Umat (Jakarta:Sinar Grafika, 2010), hlm. 99.

${ }^{2}$ Achmad Djunaidi,Thobieb Al-Asyhar, Menuju Era Wakaf Produktif; Sebuah Upaya Progresif Untuk Kesejahteraan Umat, cet II, ( Jakarta:Mitra abadi Press, 2005), hlm.v-vi

${ }^{3}$ Undang-undang Nomor 41 Tahun 2004 tentang Wakaf

${ }^{4}$ Achmad Arief Budiman, Akuntabiltas Lembaga Pengelolaan Wakaf,( Semarang, 2011, Jurnal Walisongo, Vol 19, No 1),hlm. 76
} 
pemanfaatan harta wakaf dan digunakan dalam bentuk produktif, misalnya upaya peningkatan kegiatan usaha dan lain sebagainya ${ }^{5}$.

Sehingga untuk tercapainya pengelolaan wakaf tunai secara profesional dibutuhkan pengelolaan wakaf tunai yang baik. Selain menerapkan pengelolaan wakaf tunai yang baik, untuk meningkatkan tingkat profesionalitas, lembaga wakaf sebagai lembaga sosial juga perlu untuk menjaga tingkat kepercayaan wakif dan juga masyarakat, yang nantinya akan mempengaruhi pada sumber dana wakaf yang diterima oleh badan wakaf.

Untuk meningkatkan kepercayaan tersebut, lembaga wakaf dapat melaksakan Good Corporate Governance. Penerapan Good Corporate Governance tidak hanya diterapkan pada organisasi bisnis baik yang bersifat profit oriented saja akan tetapi juga perlu diterapkan pada lembaga atau perusahaa nirlaba. Pada organisasi bisnis baik yang bersifat profit oriented maupun organisasi nirlaba selama telah ada penyerahan mandat pengelolaan tugas - tugas organisasi kepada pihak lain maka agency theory (teori keagenan) akan berlaku dalam organisasi tersebut. Teori keagenan melihat pihak manajemen perusahaan berperan sebagai agen bagi pemilik atau stakeholder perusahaan. Pihak manajemen bertindak penuh kesadaran bagi kepentingan pribadinya6 ${ }^{6}$ Pada lembaga wakaf agency theory juga berlaku dimana lembaga wakaf sebagai pihak yang menjalakan amanah dari para wakif.

Salah satu lembaga wakaf yang sudah mengelola wakaf tunai adalah Badan Wakaf Uang Tunai Majelis Ulama Indonesia Daerah Istimewa Yogyakarta. BWUT MUI DIY mengelola wakaf tunai sejak 2008 dengan bekerjasama BPD DIY Syariah sebagai Lembaga Keuangan Syariah Penerima Wakaf Uang (LKS PWU).

Dalam pengelolaan wakaf tunai yang dilakukan oleh BWUT MUI DIY selama ini terdapat beberapa kendala yang dihadapi baik kendala yang disebabkan oleh faktor internal ataupun external. Laporan terahir yang dikeluarkan oleh BWU/T MUI DIY terkait dengan dana yang sudah dikumpulkan

${ }^{5}$ Fadillah Mughnisani, "Pengelolaan Wakaf Tunai di Yayasan Wakaf Universitas Muslim Indonesia”, http://journal.uin-alauddin.ac.id/index.php/Iqtisaduna/ diakses pada 23 Maret 2017 pada pukul 14.29 WIB

${ }^{6}$ Thomas S. Kaihatu,Good Governance dan Penerapannya di Indonesia,Jurnal Manajemen dan Kewirausahaan, Jurusan Ekonomi Manajemen, Fakultas Ekonomi Universitas Kristen Petra Surabaya, Vol. 8, Nomor 1, Maret 2006, hlm. 23 
dari tahun 2008 hingga tahun 2016 belum menunjukkan angka sampai satu milyar, tepatnya adalah Rp 536.511.033. Padahal terdapat akumulasi jumlah wakif dari tahun 2008 - 2016 sebanyak 1677 orang7.

Selain itu BWU/T MUI DIY yang sudah ada sejak tahun 2008 dan berada langsung dibawah naungan MUI Yogyakarta, ternyata sampai saat ini masih belum terdaftar sebagai lembaga pengelola wakaf tunai pada pihak BWI. Bahkan sampai saat ini belum ada sekalipun bentuk laporan baik keuangan atupun kegiatan yang diberikan baik kepada BWI, wakif, maupun kepada masyarakat secara umum. Hal ini menjadi sangat berlawanan dengan prinsip transparasi yang seharusnya di lakukan oleh lembaga wakaf.

Tujuan dari adanya penelitian ini adalah mengetahui pengelolaan wakaf tunai yang dilakukan oleh BWU/T MUI DIY serta mendeskripsikan penerapan prinsip-prinsip Good Corporate Governance pada BWU/T MUI DIY dalam pengelolaan wakaf tunai.

\section{B. KAJIAN TEORI}

\section{Pengergtian dan Dasar Hukum Wakaf Tunai}

Dengan melihat perkembangan zaman, dan sesuatu yang tidak dapat dihindarkan lagi tentang pentingnya uang (bentuk kontan) dalam bertransaksi, maka kalangan ulama' Indonesia, dalam hal ini adalah MUI telah merespon positif wakaf tunai. Pada tanggal 11 Mei 2002 MUI mengeluarkan fatwa tentang diperbolehkannya wakaf tunai (waqf al-nuqud), dengan syarat nilai pokok wakaf dijamin kelestariannya dan dapat dimanfaatkan untuk waktu yang tidak terbatas 8 .

Menurut Fatwa Majelis Ulama Indonesia Tahun 2002 tentang Wakaf Tunai, bahwa wakaf tunai (cash waqf) adalah wakaf yang dilakukan seseorang, kelompok orang, dan lembaga atau badan hukum dalam bentuk uang tunai ${ }^{\text {. }}$ Sedangkan menurut Bank Indonesia mendefinisikan bahwa wakaf tunai adalah penyerahan asset wakaf berupa uang tunai yang tidak dapat dipindah

\footnotetext{
${ }^{7}$ M.Mas'udi dkk, Laporan BWT MUI DIY tahun 2016 dalam Analisis terhadap Pengembangan Wakaf Tunai (waqf Nuqud) di Indonesia, Fakultas Agama Islam, Universitas Muhamadiyah Yogyakarta, hlm. 48

${ }^{8}$ Suhrawardi K. Lubis, dkk., Wakaf,,,hlm. 103

${ }^{9}$ Kementrian Agama Republik Indonesia. Tanya Jawab Wakaf Uang (Jakarta: Direktorat Jenderal Bimbingan Masyarakat Islam Direktorat Pemberdayaan Wakaf,2011), hlm.11
} 
tangankan dan dibekukan selain untuk kepentingan yang tidak mengurangi ataupun menghilangkan jumlah pokoknya ${ }^{10}$.

Dilihat dari pengertian wakaf tunai secara lebih terperinci dapat merujuk dari peraturan BWI No 1 Tahun 2009 tentang Pedoman Pengelolaan dan Pengembangan Harta Benda wakaf Bergerak Berupa Uang, pada Pasal 1 ayat ke 3 disebutkan bahwa wakaf harta benda bergerak berupa uang yang selanjutnya disebut wakaf uang adalah wakaf berupa uang yang dapat dikelola secara produktif, hasilnya dimanfaatkan untuk mauqufalaih ${ }^{11}$.

Untuk dasar hukum wakaf tunai sama halnya seperti dasar hukum wakaf secara umum. Bahwa wakaf tidak terdapat dalam Al-Qur'an dan asSunnah, begitupun juga dengan wakaf tunai. Namun makna dan kandungan wakaf tunai terdapat dalam dua sumber hukum Islam tersebut.

Untuk dasar hukum wakaf tunai di dalam Al-Qur'an sering menggunakan dengan istilah-istilah berbuat kebajikan atau kebaikan, sebagaimana yang tercantum dalam Al-Qur'an, surat Ali Imran ayat 92, surat Al-Baqarah ayat 267 yang sudah disebutkan sebelumnya pada dasar hukum wakaf.

\section{Pengelolaan Wakaf Tunai}

\section{a. Penghimpunan Wakaf Tunai}

Penghimpunan dana (fundraising) merupakan kegiatan penggalangan dana, baik dari individu, organisasi, maupun badan hukum. Adapun yang dimaksud metode atau teknik fundraising adalah suatu bentuk kegiatan yang khas yang dilakukan oleh nazhir dalam rangka menghimpun dana/daya dari masyarakat. Metode penghimpunan dana pada dasarnya dapat dibagi kepada dua jenis, yaitu langsung (direct) dan tidak langsung (indirect) ${ }^{12}$. Untuk penghimpunan wakaf tunai telah diatur dalam Peraturan Badan Wakaf Indonesia Nomor 01 Tahun 2009 Tentang Pedoman Pengelolaan dan Pengembangan Harta Benda Wakaf Bergerak

\footnotetext{
${ }^{10}$ Direktorat Pemberdayaan Wakaf,. Pedoman Pengelolan Wakaf Tunai (Jakarta: Direktorat Pemberdayaan Wakaf Direktorat Jenderal Bimbingan Masyarakat Islam, 2006), hlm. 23

${ }^{11}$ Peraturan BWI No 1 Tahun 2009

${ }^{12}$ Zaim Saidi, Kewiraswastaan Sosial Strategi Pengembangan Bisnis Berwawasan Sosial bagi Lembaga Swadaya Masyarakat (LSM), dalam, Miftahul Huda,Model Manajemen Fundraising Wakaf, Jurnal Ahkam: Vol XIII, No 1,(Januari 2013), hlm. 35
} 
Berupa Uang. Dalam undang-undang tersebut pada bagian III tepatnya pada pasal ke 4 mengenani setoran wakaf uang disebutkan bahwa setoran wakaf uang dapat dilakukan secara langsung dan tidak langsung. Dimana setoran wakaf uang secara langsung adalah wakif atau kuasanya hadir di kantor LKS-PWU sedangkan untuk setoran tidak langsung adalah melalui media electronic channel, antara lain: Anjungan Tunai Mandiri (ATM), Phone Banking, Internet Banking, dan Mobile Banking13.

\section{b. Pendistribusian Wakaf Tunai}

Pendistribusian berasal dari kata dasar distribusi yang berarti penyaluran (pembagian, pengiriman) kepada beberapa orang atau ke beberapa tempat. Sedangkan menurut Kamus Besar Bahasa Indonesia pendistribusian mempunyai arti proses, cara, perbuatan mendistribusikan ${ }^{14}$.

Terkait pendisribusian wakaf tunai atau penyaluran manfaat dari wakaf tunai sudah diatur dalam Peraturan Badan Wakaf Indonesia Nomor 01 Tahun 2009 pada BAB IV pada pasal 13 sampai 15. Dijelaskan bahwa penyaluran manfaat dari wakaf tunai dapat dilakukan baik secara langsung maupun tidak langsung. Penyaluran manfaat hasil investasi Wakaf Uang secara langsung adalah program pembinaan dan pemberdayaan masyarakat yang secara langsung dikelola oleh Nazhir sedangkan Penyaluran manfaat hasil investasi Wakaf Uang secara tidak langsung sebagaimana dimaksud pada ayat (1) adalah program pembinaan dan pemberdayaan masyarakat melalui kemitraan dengan lembaga pemberdayaan lain yang memenuhi kriteria kelayakan kelembagaan dan profesional ${ }^{15}$.

\section{c. Pelaporan dan Pengawasan Wakaf Tunai}

Adanya pelaporan dan pengawasan tentang dana wakaf tunai yang diterima serta dikelola oleh lembaga wakaf sudah diatur dalam Peraturan

\footnotetext{
${ }^{13}$ Peraturan Badan Wakaf Indonesia Nomor 01 Tahun 2009

${ }^{14}$ Muhammad Afdhal, Proses Kegiatan Penghimpunan dan Pendistribusian Wakaf Tunai di Baitul Maal Hidayatullah Surabaya, Jurnal Ekonomi Syariah Teori dan Terapan, Vol. 3 No.6 (Juni 2016), hlm. 495

${ }^{15}$ Peraturan Badan Wakaf Indonesia Nomor 01 Tahun 2009
} 
Menteri Agama Republik Indonesia Nomor 4 Tahun 2009 tentang Administrasi Pendaftaran Wakaf Uang.

Dalam peraturan tersebut pada BAB IV pasal 9 disebutkan bahwa Nazhir wajib menyampaikan laporan pengelolaan wakaf uang setiap 6 (enam) bulan kepada BWI dengan tembusan kepada Direktur Jenderal. Laporan pengelolaan sebagaimana dimaksud meliputi: pelaksanaan pengelolaan, pengembangan, penggunaan hasil pengelolaan wakaf uang dan rencana pengembangan pada tahun berikutnya dan disampaikan paling lambat 3 (tiga) bulan sejak akhir tahun buku'16.

Selanjutnya terkait dengan pengawasan dijelaskan pada BAB IV pasal 10 dijelaskan bahwa Direktur Jenderal atas nama Menteri melakukan pengawasan wakaf uang yang dilakukan oleh LKS-PWU. Pengawasan sebagaimana dimaksud pada dilakukan melalui laporan tahunan, monitoring dan evaluasi wakaf uang pada LKS-PWU. Selain pengawasan yang dilakukan oleh Direktur Jendral pengawasan juga dapat dilakukan oleh BWI terhadap pengelolaan dan pengembangan wakaf uang yang dilakukan oleh Nazhirit.

Terkait peran masyarakat dalam melakukan pengawasan juga dijelaskan dalam peraturan tersebut pada pasal 12 dijelasakan bahwa, masyarakat dapat melakukan pengawasan terhadap pelaksanaan tugas Nazhir. Pengawasan sebagaimana yang dimaksud yakni dilakukan dengan menyampaikan laporan adanya indikasi pelanggaran terhadap ketentuan peraturan perundangundangan secara tertulis kepada kantor Departemen Agama kabupaten/kota dan/atau BWI ${ }^{18}$.

\section{Good Corporate Governance}

Good Corporate Governance (GCG) merupakan istilah yang populer dan telah menjadi topik bahasan utama serat terus dikaji oleh para pelaku bisnis, akademisi, pembuat kebijakan, dan lain sebagainya. Pemahaman tentang praktik good corporate governance terus mengalami perkembangan

${ }^{16}$ Peraturan Menteri Agama Administrasi Pendaftaran Wakaf Uang.

Republik Indonesia Nomor 4 Tahun 2009 tentang 
dari waktu ke waktu seiring dengan kompleksitas dan tekanan persaingan bisnis yang dihadapi perusahaan ${ }^{19}$.

Istilah Corporate Governance terdiri atas dua kata, yaitu corporate dan governance. secara bahasa, corporate dalam Oxford Advance Learnes Dictionary ${ }^{20}$ adalah united in a single group, sedangkan governance ${ }^{21}$ adalah the activity or manner of governing. Peraturan Menteri Negara Badan Usaha Milik Negara (BUMN) menyebutkan bahwa Good Corporate Governance adalah prinsip-prinsip yang mendasari suatu proses dan mekanisme pengelolaan perusahaan berlandaskan peraturan perundang-undangan dan etika berusaha. Tujuannya adalah untuk mengoptimalkan nilai perusahaan agar memiliki daya saing yang kuat, baik secara nasional maupun internasional, sehingga mampu mempertahankan keberadaannya dan hidup berkelanjutan untuk mencapai maksud dan tujuan perusahaan ${ }^{22}$.

Agar dapat berjalan secara sehat sesuai dengan arah yang ditetapkan, maka diperlukan prinsip-prinsip yang harus diperhatikan dalam penerapan Good Corporate Governance oleh perusahaan atau organisasi. Prinsip-prinsip tersebut adalah transparasi (transparency), akuntabilitas (accountability), pertanggungjawaban (responsibility), kemandirian (independency), dan kewajaran-kejujuran-keadilan (fairnes). Dengan demikian, implementasi konsep good corporate governance dalam pengelolaan perusahaan adalah upaya menerpakan prinsip-prinsip Good Corporate Governance dalam aturan main, prosedur, dan hubungan antara pihak yang mengambil keputusan dengan pihak yang akan melakukan pengawasan terhadap keputusan tersebut ${ }^{23}$.

${ }^{19}$ Rahmani Timorita Yulianti,Good Corporate Giovernance di Lembaga Zakat, (Yogyakarta: Kaukaba, 2016), hlm. 7

${ }^{20}$ Jonathan Crowther (ed), Oxford Advance Learnes Dictionary of Current English, Fifth Edition ( Inggris: Oxford University Press, 1995), dalam Good Corporate Governance di Lembaga Zakat, oleh Rahmani Timorita Yulianti, (Yogyakarta : Kaukaba, 2016), hlm. 9

21 ibid, hlm. 10

${ }^{22}$ Peraturan Menteri Negara Badan Usaha Milik Negara No : Per-01/Mbu/2011 Tentang Penerapan Tata Kelola Perusahaan Yang Baik (Good Corporate Governance) Pada Badan Usaha Milik Negara Pasal 1 No. 1.

${ }^{23}$ Rahmani Timorita Yulianti, Good,,, hlm. 19 
Dalam bukunya Good Corporate Governance di Lembaga Zakat, Rahmani Timorita Yulianti menyebutkan indikator-indikator dalam masing-masing prinsip good corporate governance, adapun indikator tersebut:

Tabel 1. Prinsip-Prinsip dan Indikator Good Corporate Governance

\begin{tabular}{|c|c|}
\hline 1 & $\begin{array}{l}\text { Transparasi } \\
\text { a. Rencana kerja tahunan } \\
\text { b. Laporan keuangan berkala triwulan ,tengah tahunan ,dan tahunan } \\
\text { c. Sitem akuntasi berbasis standar akutansi } \\
\text { d. Teknologi informasi dalam sistem pelaopran kegiatan dan keuangan } \\
\text { e. Sistem manajemen informasi } \\
\text { f. Laporan kegiatan dan keuangan insidental } \\
\text { g. Informasi penting tentang kegiatan insidental }\end{array}$ \\
\hline 2 & $\begin{array}{l}\text { Akuntabilitas } \\
\text { a. Penyiapan laporan keuangan secara cepat dan tepat } \\
\text { b. Komite audit dan manajemen resiko Kordinasi program kerja } \\
\text { c. Monitoring program kerja/kegiatan } \\
\text { d. Evaluasi program kerja/kegiatan }\end{array}$ \\
\hline 3 & $\begin{array}{l}\text { Responsibilitas } \\
\text { a. Anggaran dasar dan Peraturan Perundang-Undangan } \\
\text { b. Kewajiban sosial perusahaan (CSR) } \\
\text { c. Kemitraan dengan masyarakat atau bina lingkungan } \\
\text { d. Keterbukaan informasi sesuai regulasi } \\
\text { e. Etika moral, dan akhlak }\end{array}$ \\
\hline 4 & $\begin{array}{l}\text { Independensi } \\
\text { a. Kondisi saling menghormati hak, kewajiban, dan tugas masing- } \\
\text { masing organ } \\
\text { b. Kondisi bahwa selain pengurus dilarang mencampuri urusan } \\
\text { lembaga } \\
\text { c. Kondisi menghindari benturan kepentingan dalam keputusan } \\
\text { d. Adanya pedoman yang jelas dan tegas tentang eksistensi organ } \\
\text { dalam lembaga }\end{array}$ \\
\hline 5 & $\begin{array}{l}\text { Kewajaran dan Kesetaraan } \\
\text { a. Terciptanya peran dan tanggungjawab setiap pengurus/organ } \\
\text { lembaga } \\
\text { b. Keadan memperlakukan muzaki dan mustahik secara adil dan jujur } \\
\text { c. Kondisi kerja yang dan aman bagi pengurus } \\
\text { d. Kondisi memperbolehkan muzaki memberikan masukan sesuai } \\
\text { ketentuan } \\
\text { e. Adanya peraturan yang melindungi kepentingan para pihak } \\
\text { f. Adanya peraturan pelaksanaan lembaga } \\
\text { g. Adanya kebijakan untuk melidungi lembaga }\end{array}$ \\
\hline
\end{tabular}

Sumber: Good Corporate Governance di Lembaga Zakat oleh Rahmani Timorota Yulianti 
Sebagaimana disebutkan sebelumnya bahwa setiap organisai atau lembaga baik itu yang bersifat profit atau pun non profit selama sudah masuk ke dalam theory agency atau mengelola dana dari pihak ketiga maka lembaga tersebut diharuskan untuk menerapkan prinsip-prinsip GCG, begitu pun juga dengan lembaga wakaf dan lembaga zakat. Sebagai lembaga publik lembaga wakaf memiliki kesamaan dengan lembaga zakat kesamaan tersebut terletak pada dana yang dikelola yang merupakan dana filantropi atau dana yang berasal dari kedermawanaan seseorang. Selain itu banyak juga saat ini lembaga zakat yang sudah merangkap juga menjadi lembaga wakaf dalam satu kepengurusan. Sehingga secara garis besar untuk penerapan prinsip-prinsip GCG pada lembaga wakaf bisa disamakan dengan lembaga zakat.

Hanya saja nantinya yang akan menjadi perbedaan pada lembaga wakaf dan lembaga zakat terletak pada pemberian nama bagi pihak yang memberikan dana dan penerima dana, dan juga bentuk pengelolaan dana tersebut dimana wakaf pokoknya harus ditahan dan tidak boleh berkurang sedangkan dana zakat bisa disalurkan keseluruhanya.

Prinsip-prinsip yang terdapat di dalam Good Corporate Governance ini bukanlah hal yang asing dalam Islam. Sebagaimana dijelaskan sebelumnya bahwa GCG mengandung prinsip-prinsip yang melindungi kepentingan stakeholder. Prinsip-prinsip tersebut adalah melalui penerapan fairness, transparancy, independent, accountability dan responsibility.

Dalam konteks good corporate governance dalam perspektif syariah, pemenuhan prinsip syariah menjadikan konsep good corporate governance yang lebih luas dari good corporate governance konvensional. Dalam Islam, kepentingan utama yang lebih utama adalah penjagaan Islam itu sendiri. Dengan kata lain, konsep good corporate governance dalam Islam lebih komprehensif dari Franco-German Model24.

\footnotetext{
${ }^{24}$ Mardian, Studi eksplorasi pengungkapan penerapan prinsip syariah (sharia compliance) di Bank Syariah. Jurnal Sebi Volume.04 No.1 (2011).
} 
Sikap kejujuran, bertanggungjawab, bisa dipercaya dan diandalkan, serta kepekaan terhadap lingkungan sosial itulah yang menjadi tujuan penerapan good corporate governance dalam suatu organisasi atau lembaga. Hal tersebut relevan dengan sikap Nabi Muhammad SAW. 15 abad yang lalu, ketika beliau membina dirinya menjadi seorang pedagang dan pemimpin profesional, beliau memiliki reputasi dan integritas luar biasa.

Dengan demikian, prinsip-prinsip good corporate governance sama dengan karakter Nabi Muhammad saw yaitu, sidik, amanah, tabligh, dan fatanah 25 . Selanjutnya Muqorobin menyatakan bahwa good corporate governance dalam Islam harus mengacu pada prinsip-prinsip tauhid, taqwa dan ridha, keseimbangan dan keadilan, serta kemaslahatan ${ }^{26}$.

\section{METODE PENELITIAN}

Penelitian ini memnggunakan penelitian deskriptif kualitatif. Sedangkan pendekatan yang digunakan dalam penelitian kulitatif ini adalah dengan menggunakan pendekatan studi kasus. Untuk mengumpulkan data pada penelitian ini mengunakan teknik wawancara, dokumentasi dan juga observasi.

Pada wawancara peneliti menggunkan purposive sampling atau sampling bertujuan untuk menentuan informan. Purposive sampling adalah teknik pengambilan sampel sumber data dengan pertimbangan tertentu. Pertimbangan tertentu ini, misalnya orang tersebut yang dianggap paling tahu tentang yang kita harapkan, atau mungkin dia sebagai penguasa sehingga akan memudahkan peneliti menjelajahi obyek atau situasi sosial yang diteliti. Sehingga dengan menggunakan teknik ini peneliti menetapkan Drs. H. Harsoyo, M.Si selaku ketua umum BWUT MUI DIY dan Zaki Ghufron, S.Pd.I selaku sekertaris sebagai informan dalam penelitian ini.

Pada penelitian ini peneliti akan menggunakan teknik analisis deskriptif kualitatif yang bermaksud untuk memahami fenomena tentang apa yang dialami oleh subjek penelitian, Analisis deskriptif ini bertujuan untuk, mendeskripsikan

\footnotetext{
${ }^{25}$ Rahmani Timorita Yulianti, Good,,, hlm. 39
}

${ }^{26}$ Masyudi Muqorobin. Fikih Tata Kelola Organisasi Laba:Sebuah Pengantar. Disampaikan pada Seminar Nasional Tata Kelola dan Rapat Kerja tanggal 25-27 Maret 2011, Universitas Muhammadiyah Purwekerto,hlm 11 
dan menganalisis pengelolaan wakaf tunai yang dilakukan oleh BWUT MUI DIY dan penerapan prinsip-prinsip good corporate governance di dalamnya.

\section{HASIL PENELITIAN DAN PEMBAHASAN}

\section{Pengelolaan Wakaf Tunai di BWUT MUI DIY}

Secara garis besar bentuk pengelolaan wakaf tunai yang dilakukan oleh BWU/T MUI DIY terbagi ke dalam tiga bagian, yakni penghimpunan dana wakaf, pengembangan dana wakaf, dan pendistribusian hasil wakaf27.

\section{a. Penghimpunan Wakaf Tunai}

Dalam melakukan penghimpunan wakaf tunai BWU/T MUI DIY mengghunakan metode langsung dan tidak langsung. Untuk metode langsung yakni dengan mendatangi pengajian-pengajian yang ada di wilayah Yogyakarta, yang kemudian dilanjutkan dengan memberikan kesempatan kepada para jamaah pengajian untuk bisa memberikan wakaf pada tempat yang sudah disediakan oleh pihak BWU/T MUI DIY. Selain dengan menggunakan metode langsung berupa pengajian dalam menghimpun wakaf tunai, BWU/T MUI DIY juga menerima wakaf tunai dengan metode tidak langsung, dimana BWU/T/T MUI DIY sudah bekerjasama dengan pihak Departemen Agama wilayah Yogyakarta dan juga Bank BPD Syariah Yogyakarta dalam memperkenalkan wakaf tunai yang ada pada BWU/T MUI DIY28.

Jika dilihat dari awal berdirinya BWU/T MUI DIY pada tahun 2008 sampai dengan tahun 2017 di setiap tahunnya ada kenaikan jumlah dana wakaf dan wakif yang diterima oleh BWU/T MUI DIY. Bahkan total dana yang wakaf tuani yang sudah terkumpul sampa saat ini sudah mencapai kurang lebih 600 juta rupiah. Diakui bahwa seharusnya nominal tersebut bisa saja lebih besar jika pihak BWUT MUI DIY lebih gencar dalam melakukan penghimpunan dana. Untuk wakif yang berhak mendapatkan SWU, sebagaimana yang ditetapkan oleh pihak BWU/T MUI adalah wakif yang memberikan wakaf dengan minimal nominal Rp. 50.000. Sedangkan untuk wakif yang ingin memberikan wakaf tunai dibawah nominal

\footnotetext{
${ }^{27}$ Wawancara dengan Zaki Ghufron di Yogyakarta, tanggal 31 Juli 2017

28 ibid
} 
tersebut tetap akan diterima oleh pihak BWU/T MUI hanya saja nantinya pihak BWU/T tidak mencetakkan SWU29.

Dilihat dari metode penghimpunan dana yang dilakukan oleh BWU/T MUI DIY sudah sesuai dengan Peraturan Badan Wakaf Indonesia Nomor 01 Tahun 2009 Tentang Pedoman Pengelolaan dan Pengembangan Harta Benda Wakaf Bergerak Berupa Uang. Dalam undang-undang tersebut pada bagian III tepatnya pada pasal ke 4 mengenani setoran wakaf uang disebutkan bahwa setoran wakaf uang dapat dilakukan secara langsung dan tidak langsung. Dimana setoran wakaf uang secara langsung adalah wakif atau kuasanya hadir di kantor LKS-PWU sedangkan untuk setoran tidak langsung adalah melalui media electronic channel, antara lain: Anjungan Tunai Mandiri (ATM), Phone Banking, Internet Banking, dan Mobile Banking ${ }^{30}$.

Hanya saja yang menjadi permasalahan dalam mekanisme penghimpunan wakaf tunai oleh BWU/T MUI terletak pada pencetakan SWU, sebagaimana yang dijelaskan dalam Peraturan Badan Wakaf Indonesia Nomor 01 Tahun 2009 pada Bagian II pasal 3 ayat ke dua bahwa wakif yang menyetorkan wakaf uang paling kurang Rp1.000.000,00 (satu juta rupiah) akan memperoleh Sertikat Wakaf Uang, sedangkan BWU/T MUI DIY mengeluarkan SWU dengan minimal wakaf di nominal Rp 50.000,00 sehinga tidak terdapat kesesuaian bahkan untuk perbandingan nominalnya juga terlalu jauh.

\section{b. Pengembangan Wakaf Tunai}

Dalam hal pengelolaan wakaf tunai untuk dikembangkan, BWU/T MUI DIY sudah bekerjasama dengan salah satu LKS PWU yang ditunjuk oleh pemerintah dalam hal ini adalah Bank BPD Yogyakarta Syariah. Sehingga seluruh dana yang masuk kepada BWU/T MUI DIY akan dimasukkan ke dalam Bank BPD Yogyakarta atas nama rekening BWU/T MUI DIY. Selain itu untuk lebih memudahkan dalam berkordinasi antara BPD DIY Syariah dengan pihak BWU/T MUI DIY, pihak BPD DIY Syariah

\footnotetext{
${ }^{29}$ ibid

${ }^{30}$ Peraturan Badan Wakaf Indonesia Nomor 01 Tahun 2009
} 
juga memberikan sekre bagi pihak BWU/T MUI DIY yang berada dalam satu tempat dengan BPD DIY Syariah ${ }^{31}$.

Terkait mekanisme pengelolaan pengembangan wakaf tunai yang dilakukan oleh BWU/T MUI DIY adalah bahwa dana wakaf tunai yang masuk kepada BPD DIY Syariah akan dimasukkan kedalam rekening tabungan mudharabah atas nama BWU/T MUI DIY dengan No.rek 500.262.777-1. Setelah dana wakaf tunai yang terkumpul pada tabungan BWU/T MUI DIY mencapai nominal yang ditentukan selanjutnya melalui persetujuan bendahara BWU/T MUI DIY dana tersebut akan dipindahkan pada rekening deposito BWU/T MUI DIY tetap pada Bank yang sama yakni BPD DIY Syariah sebagai LKS PWU32.

Selanjutnya disebutkan oleh Zaki Gufhron bahwa sampai saat ini nominal bagi hasil yang sudah diterima oleh BWU/T MUI DIY sudah mencapai nominal Rp. 100.000.000,00 yang mana keseluruhan dana bagi hasil tersebut sudah berhasil diputarkan, karena BWU/T MUI DIY memiliki prinsip bahwa semakin cepat dana diputarkan maka akan semakin memeberikan manfaat dari pada dana harus mengendap.

Dilihat dari segi pengelolaan wakaf tunai yang dilakukan oleh BWU/T MUI DIY maka dapat disimpulkan bahwa pengelolaanya sudah sesuai dengan regulasi yang ada agar dana wakaf dikelola oleh lembaga keuangang yang resmi ditunjuk oleh Pemerintah dan Bwi, dalam hal ini adalah Bank BPD DIY Syariah.

Sebagaimana diatur dalam UU No. 41 tahun 2004 tentang Wakaf pasal 28, penerimaan wakaf uang dapat dilakukan melalui Lembaga Keuangan Syariah Penerima Wakaf Uang (LKS-PWU) yang ditunjuk oleh menteri. Bank BPD DIY Syariah merupakan salah satu lembaga keuangan syariah yang memenuhi persyaratan untuk mengelola dan mengembangkan wakaf uang. Pengelolaan dan pengembangan wakaf uang di Bank BPD DIY Syariah yaitu, Bank BPD DIY Syariah berperan dan menempati posisi sebagai penyimpan dana pokok wakaf. Dalam

\footnotetext{
${ }^{31}$ Wawancara dengan Zaki Ghufron di Yogyakarta, tanggal 31 Juli 2017

32 ibid
} 
pengelolaannya wakaf uang tersebut nantinya akan berbentuk rekening tabungan dan setelah terkumpul dana wakaf pokok uang sebesar 10jt akan dipindah ke dalam bentuk deposito, sehingga nanti akan muncul bagi hasil. Bagi hasil tersebut yang nantinya akan di salurkan ke masyarakat atau kelompok yang membutuhkan sebagai modal usaha, melaui kerjasama dengan BWU/T MUI DIYsebagai pihak nazhir wakaf tunai ${ }^{33}$.

\section{c. Pendistribusian Wakaf Tunai}

Untuk proses pendistribusian, dalam kepengurusan BWU/T MUI DIY memiliki bagian tersendiri yang disebut dengan seksi pentasarufan atau penyaluran dana. Tugas dan wewenang dari seksi pentasarufan ini secara garis besar adalah menentukan dan mempertimbangkan mauquf alaih mana saja yang akan menerima hasil dari wakaf tunai. Selain menetukan dan mempertimbangkan, tugas dari seksi pentasarufan adalah mendampingi dan memberikan pembinaan mauquf alaih selama proses berjalannya kerjasama antara BWU/T MUI DIY dengan mauquf alaih ${ }^{34}$.

Untuk pendisrtibusian dana yang dilakukan, BWU/T MUI DIY memiliki beberapa bentuk atau model kegiatan. Untuk model produktif, terdiri dari penyaluran untuk bisnis riil dan investasi produk keuangan syariah. Sedangkan untuk bentuk sosial, terdiri dari penyaluran untuk pendidikan dan kesehatan. Selain dalam bentuk produktif dan sosial, BWU/T MUI DIY juga memeiliki kegiatan penyaluran manfaat yakni dengan memberikan Pinjaman Produktif Tanpa Agunan dan Biaya (PROTAB 1) Reguler yang dapat diangsur bulanan selama 1 tahun dengan maksimal pinjaman saat ini mecapai nominal Rp 700.000, Pinjaman Produktif Tanpa Agunan dan Biaya (PROTAB 2) juga dapat diangsur bulanan selama 1 tahun dengan maksimal pinjaman Rp 3.000.000 dan juga Sebrakan yakni pinjaman yang dilakukan dengan nominal yang cukup besar dengan jangka waktu pengembalian yang lebih pendek ${ }^{35}$.

\footnotetext{
${ }^{33}$ Hendro Setyadi, Pengelolaan Pengembangan Wakaf Uang Berdasarkan Peraturan Pemerintah No. 42 Tahun 2006 Pasal 48 Pada Bank BPD DIY Syariah, Jurnal Iqtishadia, Vol. 2, No. 1, Maret 2017

${ }^{34}$ Wawancara dengan Zaki Ghufron di Yogyakarta, tanggal 31 Juli 2017

${ }^{35}$ Wawancara dengan Harsoyo di Yogyakarta, tanggal 18 Juli 2017
} 
Sasaran atau tujuan yang ditetapkan oleh BWU/T MUI DIY dalam menentukan pendistribusian dana bagi hasil wakaf tunai adalah pada sektor perekonomian mikro pedesaan, sehingga untuk dana yang diberikan tidak terlalu besar akan tetapi dapat memberikan manfaat yang maksimal. Dengan adanya pinjaman tanpa biaya dan jaminan yang diberikan kepada masyarakat pedesaan diharapkan mampu membantu perekonomian masyarakat yang tidak memilki modal dan juga jaminan sebagai tambahan modal usaha mikro. Harsoyo menambahkan pada sektor usaha perdagangan, bahwa yang diperjual belikan adalah barangbarang yang dapat diproduksi atau didapatkan dari sekitar masyarakat seperti berjualan jamu, sayur-sayuran, makanan ringan dan lain sebagainya. Sampai saat ini bentuk pendistribusian dana bagi hasil wakaf tunai BWU/T MUI DIY juga sudah menjadi contoh bagi lembaga-lembaga wakaf lainya, karena dinilai model pendistribusian yang dilakukan oleh BWU/T MUI DIY mampu berperan besar dalam meningkatkan sektor perekonomian masyarakat menengah ke bawah ${ }^{36}$.

Jika ditinjau dari segi pendistribusian yang dilakukan oleh BWU/T MUI DIY selama ini maka dapat disimpulkan bahwa pendistribusian yang dilakukan sudah sesuai dengan Peraturan Badan Wakaf Indonesia Nomor 01 Tahun 2009 Tentang Pedoman Pengelolaan dan Pengembangan Harta Benda Wakaf Bergerak Berupa Uang. Pada Bab VI pasal ke 13 dalam peraturan tersebut disebutkan bahwa penyaluran manfaat hasil investasi wakaf uang dapat dilakukan secara langsung dan tidak langsung ${ }^{37}$. Dimana BWU/T MUI DIY menyalurkan manfaat hasil dari wakaf tunai secara langsung kepada mauquf alaih setelah melalui proses pertimbangan kepengurusan dan juga menyalurkan manfaat hasil dari wakaf tunai secara tidak langsung dengan bekerjasama dengan Bank BPD Yogyakarta Syariah.

Selain itu untuk program yang dijalankan oleh BWU/T MUI DIY dengan mengarah kepada sektor produktif, sosial, dan perekonomian

\footnotetext{
${ }^{36}$ ibid

${ }^{37}$ Peraturan Badan Wakaf Indonesia Nomor 01 Tahun 2009
} 
mikro pedesaan juga sudah sesuai dengan Peraturan Badan Wakaf Indonesia Nomor 01 Tahun 2009 yang terdapat pada pasal ke 14 bahwa penyaluran manfaat hasil investasi wakaf uang secara langsung dapat dilakukan melalui program pembinaan dan pemberdayaan masyarakat yang dijalankan sesuai dengan syariah seperti program sosial, program pendidikan, program kesehatan, program ekonomi berupa pembinaan dan bantuan modal usaha mikro, dan juga program dakwah berupa penyediaan da'i dan mubaligh.

\section{Penerapan Prinsip-Prinsip Good Corporate Governance pada Pengelolaan Wakaf Tunai BWU/T MUI DIY}

a. Transparasi (transparency)

Bentuk transparasi yang dilakukan oleh BWU/T MUI DIY selama ini yakni dengan memberikan laporan keuangan dan laporan kegiatan kepada masyarakat luas. Hanya saja sampai saat ini BWU/T MUI belum memberikan kemudahan akses bagi masyarakat untuk mengetahui laporan keuangan dan laporan kegiatan yang dilakukan oleh BWU/T MUI DIY. Bentuk laporan keuangan dan kegiatan BWU/T MUI DIY hanya disampaikan melalui presentasi saat ada pengenalan wakaf tunai melalui pengajian, ataupun perkumpulan yang difasilitasi oleh kemenag, serta memberikan informasi pelaporan kepada mereka yang meminta secara langsung kepada BWU/T MUI DIY, seperti ketika ada proses penelitian dari mahasiswa dan lain sebagainya ${ }^{38}$.

Jika dilihat dari kesembilan indikator-indikator prinsip transparasi dapat disimpulkan BWU/T MUI DIY dalam menerapkan prinsip transparsi hanya terpenuhi pada laporan keuangan berkala tahunan saja. Untuk rencana kerja tahunan diakui oleh Harsoyo bahwa pernah diadakan sebelumnya namun tidak secara rutin setiap tahunya, sedangkan untuk penyusunan keuangan berkala triwulan dan tengah tahunan sudah menjadi satu dengan laporan berkala tahunan, untuk sistem akuntansi berbasis standar akuntasi diakui

${ }^{38}$ Wawancara dengan Harsoyo di Yogyakarta, tanggal 18 Juli 2017 
sampai saat ini juga belum terlaksana karena sampai saat ini juga belum ada sistem akuntansi untuk wakaf, terkait teknologi informasi dalam sistem pelaporan kegiatan dan keuangan juga belum dimanfaatkan sebaik mungkin.

\section{b. Akuntabilitas}

Dalam pelaksanaan prinsip akuntabilitas yang dilakukan oleh BWU/T MUI DIY disampaikan oleh Harsoyo selaku ketua pelaksana BWU/T MUI DIY bahwa sampai saat ini dapat dikatakan sangat lemah. Ini dapat dilihat dari beberapa indikator yang tidak terpenuhi. Seperti penyiapan laporan keuangan secara cepat dan tepat diakui bahwa saat ini masih banyak kekurangan yang dialami oleh BWU/T MUI DIY baik dari segi penyusunan laporan keuangan tersebut maupun dari segi bentuk pelaporanya ${ }^{39}$

Selanjutnya terkait dengan komite audit dan manajemen resiko juga belum berjalan dengan baik, meskipun BWU/T MUI sudah memiliki audit internal tersendiri dalam susunan kepengurusan namun diakui sampai saat ini belum berjalan sesuai dengan yang diharapkan, selain itu disampaikan bahwa sampai saat ini juga belum ada bentuk auditing dari pihak eksternal. Selain itu terkait dengan kordinasi program kerja, monitoring program kerja/ kegiatan, dan evaluasi program kerja/ kegiatan juga belum berjalan secara maksimal. Kendala yang dihadapi oleh BWU/T MUI DIY adalah kesibukan dari masing-masing pengurus yang memiliki tanggunjawab diluar kepengurusan nazhir BWU/T MUI DIY, yang menyebabkan masing-masing pengurus mengalami kesulitan untuk berkordinasi satu sama lain ${ }^{40}$.

Jika dilihat dari banyaknya indikator-indikator akuntabilas yang tidak terpenuhi oleh kepengurusan BWU/T MUI DIY maka dapat disimpulkan bahwa saat ini untuk penerapan prinsip akuntabilitas BWU/T MUI DIY masih sangat lemah. Sehingga

\footnotetext{
${ }^{39}$ ibid

${ }^{40}$ Wawancara dengan Harsoyo di Yogyakarta, tanggal 18 Juli 2017
} 
diharapkan kedepannya BWU/T MUI DIY dapat menerapkan prinsip akuntabilitas secara utuh, dengan cara masing-masing pengurus dapat bertanggungjawab terhadap tugas masing-masing yang sudah diamanahkan.

\section{c. Responsibilitas}

Terkait dengan penerapan prinsip responsibilitas yang dilakukan oleh BWU/T MUI DIY terdapat kekurangan. Kekurangan tersebut terletak pada peraturan perundang-undangan terkait dengan pendaftaran BWU/T MUI DIY sebagai nazhir wakaf tunai. Dijelaskan bahwa sampai saat ini BWU/T MUI DIY masih belum memilki badan hukum yang jelas dan juga belum terdaftar di pihak BWI sebagai nazhir wakaf tunai. Dijelaskan oleh Harsoyo bahwa belum terdaftaranya BWU/T MUI DIY sebagai nazhir wakaf tunai di pihak BWI dikarenakan status BWU/T MUI DIY yang berada di bawah naungan MUI sedangkan sampai saat ini MUI juga belum memiliki badan hukum yang jelas ${ }^{41}$.

Sebagaimana dijelaskan dalam Peraturan Badan Wakaf Indonesia Nomor 2 Tahun 2010 tentang tatacara pendaftaran nazhir wakaf uang, disebutkan pada pasal 2 dalam undang-undang tersebut bahwa "Calon Nazhir Wakaf Uang wajib mendaftarkan diri kepada BWI dan memenuhi persyaratan Nazhir sesuai Undang-Undang Nomor 41 Tahun 2004 Tentang Wakaf dan Peraturan Pemerintah Nomor 42 Tahun 2006 Tentang Pelaksanaan Undang-Undang Nomor 41 Tahun 2004 Tentang Wakaf ${ }^{42}$.

Jika dilihat dari penerapan prinsip responsibilitas BWU/T MUI DIY secara keseluruhan bahwa sampai saat ini masih belum terlaksana secara penuh. Kekurangan yang ada terletak pada bentuk legalitas BWU/T MUI DIY sebagai pengelola wakaf tunai karena belum terdaftar di pihak BWI sebagai lembaga yang mengayomi lembagalembaga wakaf di Indonesia. Sehingga diharapkan BWU/T MUI DIY

\footnotetext{
${ }^{41}$ ibid

${ }^{42}$ Peraturan Badan Wakaf Indonesia Nomor 01 Tahun 2009
} 
sebagai nazhir wakaf tunai yang sudah berdiri sejak tahun 2008 ini dapat segera menyelesaikan proses pendaftaran kepada pihak BWI supaya menjadi lembaga wakaf yang diakui, dan juga berpengaruh terhadap tingkat kepercayaan masyarakat umum.

\section{d. Kemandirian}

Diakui oleh Harsoyo untuk tingkat indepedensi BWU/T MUI DIY sangatlah kuat, artinya sampai saat ini tidak ada intervensi terkait dengan kebijakan-kebijakan dan urusan lembaga dari pihak manapun. Disampaikan untuk kerjasama dengan pihak Banak BPD DIY Syariah selaku LKS PWU berjalan dengan baik, dan mampu menjalankan hak dan kewajiban masing-masing dimana BWU/T MUI DIY sebagai nazhir dan Bank BPD DIY Syariah sebagai LKS PWU43.

Dilihat dari keempat indikator-indikator prinsip kemandirian maka dapat disimpulkan bahwa sampai saat ini BWU/T MUI DIY sudah menerapkan prinsip indepedensi secara menyeluruh. Dilihat dari adanya saling menghormati hak dan kewajiban masing-masing organisasi yang bekerjasama, tidak adanya intervensi dari pihak manapun terkait dengan kebijakan-kebijakan dan urusan lembaga, sikap profesionalitas yang dilakukan oleh pengurus sehingga tidak memunculkan kepentingan pribadi ataupun kelompok dalam keputusan, dan tentang adanya pedoman yang jelas dan tegas tentang eksistensi organ.

\section{e. Kewajaran dan Kesetaraan (Fairness)}

Untuk dapat mengetahui seberapa besar prinsip fairness ini dijalankan dibutuhkan indikator-indikator yang berdasarkan pada pengertian mengenai prinsip fairness tersebut. Adapun indikatorindikator tersebut adalah terciptanya peran dan tanggungjawab setiap pengurus/organ lembaga; keadaan memperlakukan wakif dan mauquf alaih secara adil dan jujur; kondisi kerja yang nyaman dan aman bagi pengurus; kondisi memperbolehkan wakif memberikan masukan sesuai ketentuan; adanya peraturan yang melindungi kepentingan

${ }^{43}$ Wawancara dengan Harsoyo di Yogyakarta, tanggal 18 Juli 2017 
para pihak; adanya peraturan pelaksanaan lembaga; adanya kebijakan untuk melidungi lembaga ${ }^{44}$.

Jika dilihat dari indikator-indikator tersebut di atas maka untuk penerapan prinsip fairness pada BWU/T MUI DIY sejauh ini dapat disimpulkan sudah memenuhi standar hanya saja ada beberapa indikator yang dianggap masih belum diterapkan secara maksimal, indikator tersebut adalah terciptanya peran dan tanggungjawab setiap pengurus.

Harsoyo selaku ketua pelaksana BWU/T MUI DIY menyatakan bahwa sampai saat ini ada beberapa pengurus yang masih belum memberikan kontribusi nyata pada sektor yang diamanahkan. Sebagian besar kendala yang dihadapi adalah karena pengurus tersebut memiliki kesibukan lain di luar dari kepengurusan BWU/T MUI DIY, sehingga ada beberapa tugas yang seharusnya dikerjakan oleh pengurus tersebut justru dikerjakan oleh pengurus yang lain ${ }^{45}$.

\section{E. KESIMPULAN}

Dilihat dari pengelolaan wakaf tunai yang dilakukan oleh BWU/T MUI DIY baik dari segi penghimpunan dana, pengembangan dana, dan juga pendistribusian dana maka dapat disimpulkan bahwa bentuk pengelolaan yang dilakukan oleh BWU/T MUI dapat dikatakan bagus, selain dikarenakan sudah sesuai dengan regulasi yang ada tujuan dari adanya wakaf tunai yang dikelola oleh BWU/T MUI sudah dapat dirasakan oleh masyarakat luas,terutama yang berada di wilayah pedesaan.

Mengenai prinsip-prinsip GCG yang dilakukan oleh BWU/T MUI DIY selama ini,dapat disimpulkan bahwa masih belum dilaksanakan secara utuh atau masih ada beberapa kekurangan. Kekurangan yang paling menonjol terletak pada penerapan prinsip transparasi dan juga akuntabilitas. Sedangkan pada prinsip responsibilitas kekurangan yang dialami hanya terletak pada pertangungjawaban pada perundang-undangan yang berlaku, dikarenakan sampai saat ini BWU/T

\footnotetext{
${ }^{44}$ Rahmani Timorita Yulianti,Good Corporate,,,.hlm. 8

${ }^{45}$ Wawancara dengan Harsoyo di Yogyakarta, tanggal 18 Juli 2017
} 
MUI DIY masih belum terdaftar sebagai nazhir wakaf tunai di pihak BWI sedangkan perundang-undangan mengharuskan bahwa nazhir wakaf tunai harus terdaftar di pihak BWI. Sedangkan terkait dengan prinsip indepedensi dan juga fairness yang diterapkan oleh BWU/T MUI DIY sudah dapat dikatakan terlaksana secara utuh dengan terpenuhinya indikator-indikator dari kedua prinsip tersebut.

\section{F. DAFTAR PUSTAKA}

Ali, Mohammad Daud, 1998, Sistem Ekonomi Islam: Zakat dan Wakaf, cet.1, Jakarta: UI Press.

Arif, Syafrudin., 2010,“Wakaf Tunai Sebagai Alternatif Mekanisme Retribusi Keuangan Islam”, Jurnal La-Riba Vol, 4, No 1, Juli 2010.

Atabik, Ahmad., 2014,"Manajemen Pengelolaan Wakaf Tunai di Indonesia", Jurnal Ziswaf, Vol 1,No.1, Juni 2014, Kudus : STAIN Kudus.

Budiman, Ahmad Arief.,2011," Akuntabiltas Lembaga Pengelolaan Wakaf", Jurnal Walisongo, Vol 19, No 1, Mei 2011, Semarang: IAIN Walisongo Semarang.

Direktorat Pemberdayaan Wakaf, 2007, Strategi Pengembangan Wakaf Tunai di Indonesia, Kemenag RI.

Djunaidi, Achmad, Thobieb Al-Asyhar, 2005, Menuju Era Wakaf Produktif; Sebuah Upaya Progresif Untuk Kesejahteraan Umat, cet II, Jakarta: Mitra abadi Press.

Fadillah Mughnisani,"Pengelolaan Wakaf Tunai di Yayasan Wakaf Universitas Muslim Indonesia",http://journal.uin-alauddin.ac.id /index.php/Iqtisaduna/, diakses pada 23 Maret 2017 pada pukul 14.29 Wib.

Hadi, A. Chairul., 2009,“Peluang wakaf Produktif untuk Pembiayaan Pendidikan Islam”, Jurnal Turats, Vol. 5, No 1, Juni 2009.

Hadi, Sutrisno., 2004, Metodologi Research, jilid 2, Yogyakarta : Penertbit Andi.

Harsoyo.,Wawancara Ketua Pelaksanaan BWU/T MUI DIY, Yogyakarta, 18 Juli 2017 Huda, Miftahul.,2014,“Manajemen Fundaraising Wakaf Potret Yayasan Badan Wakaf.

Universitas Islam Indonesia Yogyakarta dalam Menggalang Wakaf", Jurnal Justitia Isalamica, Vol. 11, No 1, Januari-Juni 2014, Ponorogo: Jurusan Syariah dan ekonomi Islam STAIN Ponorogo.

Huda, Nurul., Desti Anggraini dkk, 2014,"Akuntabilitas Sebagai Sebuah solusi Pengelolaan Wakaf", Jurnal Akuntansi Multiparadigma,Vol 5, No 3, Desember 2014, Malang. 
Kaihatu, Thomas S., 2006, “Good Corporate Governance dan Penerapannya di Indonesia", Jurnal Manajemen dan Kewirausahaan.

Komite Nasional Kebijakan Governance, 2006, Pedoman Umum Good Corporate Governance Indonesia.

Lubis, Suhrawardi K., dkk., 2010, Wakaf dan Pemberdayaan Umat, Jakarta: Sinar Grafika.

Maradita, Aldira., 2014, "Karakteristik Good Corporate Governance pada Bank Syariah dan Bank Konvensional", Jurnal Yuridika, Vol 29, No 2, MeiAgustus 2014.

Maulidan, 2015,“Pengaruh Good Corporate Governance dan Corporate Fianancial Performance terhadap Corporate Social Responsbility", Jurnal Dinamika Akuntan dan Bisnis Vol.2 No. 2, 2015.

Moleong, Lexy J., 1994, Metodelogi Penelitian Kualitatif, edisi revisi, Bandung:Remaja Rosdakarya.

Musthofa, Najibah., dan Mohd Zamro Huda, 2014, “Educational Waqf Management in Malasia's Higher Education Instititions: Review of Literature", Jurnal IJMS 21,No 2, 2014, hlm. 63-81, Malaysia: Fakulti Pengajian Pengajian Islam Universiti Kebangsaan Malaysia.

PBI No. 11/33/PBI/2009 Tentang Pelaksanaan GCG Bagi BUS Dan UUS Pasal 1 ayat 10 .

Peraturan BWI NO 1 Tahun 2009 tentang Pedoman Pengelolaan dan Pengembangan Harta Benda Wakaf Bergerak Berupa Uang.

Peraturan BWI NO 2 Tahun 2010 tentang Tata Cara Pendaftaran Nazhir Wakaf Uang Peraturan Menteri Agama NO 4 Tahun 2009 tentang Administrasi Pendaftaran Wakaf Uang.

Peraturan Menteri Negara Badan Usaha Milik Negara No: Per-01/Mbu/2011 Tentang Penerapan Tata Kelola Perusahaan Yang Baik (Good Corporate Governance) Pada Badan Usaha Milik Negara Pasal 1 No. 1.

Tjager, I Nyoman., DKK, 2003, Corporate Governance, Jakarta: PT. Prenhalindo. Undang-undang Nomor 41 Tahun 2004 tentang Wakaf.

Undang-Undang Nomor 42 Tahun 2006 tentang Pelaksanaan Undang-undang Nomor 41 Tahun 2004 tentang Wakaf.

Wadjdy, Farid., Mursyid, 2007, Wakaf dan Kesejahteraan Umat, Yogyakarta : Pustaka pelajar.

Yulianti, Rahmani Timorita., 20016, Good Corporate Governance di Lembaga Zakat, Yogyakarta: Kaukaba.

Zaki Ghufron, Wawancara Sekertaris BWU/T MUI DIY, Yogyakarta, 31 Juli 2017. 